\title{
Gambaran Penerapan Prinsip Higiene Sanitasi Makanan Di PT Aerofood Indonesia, Tangerang, Banten
}

\section{The Description of Food Sanitation and Hygiene At PT Aerofood Indonesia, Tangerang, Banten}

\author{
Dini Rahmadhani*1, Sri Sumarmi ${ }^{1}$
}

\begin{abstract}
ABSTRAK
Latar Belakang: PT. Aerofood Indonesia adalah salah satu penyedia katering untuk penerbangan atau inflight catering bertaraf internasional dan merupakan penyedia logistik penerbangan, terutama logistik untuk penerbangan Garuda Indonesia. Perusahaan yang berdiri sejak 1970 ini memiliki visi untuk menjadi penyedia jasa makanan dan layanan berkualitas premium di Asia Tenggara. Untuk mencapai visinya, salah satu upaya agar makanan berkualitas adalah dengan menerapkan higiene sanitasi makanan.

Tujuan: Tujuan dari penulisan artikel ini adalah untuk mengetahui dan mempelajari penerapan higiene dan sanitasi makanan khususnya pada main course Garuda Indonesia yang diproduksi oleh PT. Aerofood Indonesia.

Metode: Jenis penelitian ini adalah penelitian deskriptif dengan menggunakan metode pendekatan kualitatif berupa observasi dan wawancara.

Hasil: Penerapan higiene sanitasi makanan dapat diterapkan pada katering skala kecil maupun skala besar. Dalam penerapannya, higiene sanitasi makanan tidak hanya memperhatikan makanan tetapi juga penjamah makanan selama proses pengolahan dan proses produksi. Hal ini sesuai dengan Undang-Undang Nomor 18 Tahun 2012 Tentang Pangan yang menyatakan bahwa sanitasi pangan adalah upaya untuk menciptakan dan mempertahankan kondisi pangan yang sehat dan higienis yang bebas dari bahaya cemaran biologis, kimia, dan benda lain. Dalam penerapan higiene sanitasi makanan, terdapat beberapa aspek yang harus diperhatikan. Terdapat enam prinsip dalam penerapan higiene sanitasi makanan, yaitu prinsip I: Pemilihan Bahan Baku Makanan, prinsip II: penyimpanan bahan makanan, prinsip III: pengolahan makanan, prinsip IV: penyimpanan makanan matang, prinsip V: pengangkutan makanan, dan prinsip VI: penyajian makanan.

Kesimpulan: Berdasarkan penelitian yang telah dilakukan, PT. Aerofood Indonesia telah menerapkan higiene sanitasi makanan dimulai dari proses penerimaan bahan makanan, penyimpanan makanan, hingga penyajian makanan. Dengan menerapkan higiene sanitasi makanan, diharapkan mampu meminimalisir terjadinya hal yang merugikan akibat makanan.
\end{abstract}

Kata Kunci: katering penerbangan, higiene sanitasi makanan, pengolahan makanan. 


\section{ABSTRACT}

Background: PT. Aerofood Indonesia is one of inflight catering with international standard, not only as inflight catering, this company also provide logistic for flight especially Garuda Indonesia. A company which was established since 1970 has a vision to become food provider and become premium service for flight in Southeast Asia. Implementation of food hygiene and sanitation is one way to achieve the vision to make quality food.

Objectives: The purpose of writing this article is to know and study the implementation of food hygiene and sanitation especially on the main course of Garuda Indonesia that processed by PT. Aerofood Indonesia.

Methods: This research is descriptive research which using qualitative approach by observation and interview method.

Results: Implementation of food hygiene and sanitation can be applied for catering with big scale and small scale. In its implementation, food hygiene and sanitation not only observe the food but also observe the food handlers. This is accordance with Undang-Undang Nomor 18 Tahun 2012 Tentang Pangan which explain that food sanitation is one efforts to create and maintain healthy food conditions and hygienic that are free from the dangers of biological, chemical, and other substances. In implementation of food hygiene and sanitation, there are several aspects that must be considered. There are six principles in implementation food hygiene and sanitation. Principle I: selection of food raw material, principle II: food storage, principle III: food processing, principle IV: storage of cooked foods, principle V: food transport, and principle VI: foods presentation.

Conclusion: Based on research that has been done, PT. Aerofood Indonesia has applied food hygiene and sanitation, starting from the process of receiving food material until food presentation. By applying food hygiene and sanitation be expected to minimize of harm caused by food.

Keywords: inflight catering, food hygiene and sanitation, food processing.

\footnotetext{
*Koresponden:

dinilambaga@gmail.com

${ }^{1}$ Departemen Gizi Kesehatan, Fakultas

Kesehatan Masyarakat-Universitas Airlangga
}

\section{PENDAHULUAN}

Makanan merupakan kebutuhan sehari-hari manusia yang harus dipenuhi. Makanan bisa menjadi salah satu penyebab terjadinya keracunan makanan dan dapat menjadi perantara dalam penularan penyakit atau dikenal dengan Food Borne Disease. Katering merupakan suatu badan usaha penyedia makanan untuk banyak orang. Untuk menghindari terjadinya keracunan makanan serta penularan penyakit melalui makanan, maka kebersihan dari makanan dan penjamah makanan harus diperhatikan karena dengan adanya kejadian tersebut maka akan menjadi hal yang serius serta mempengaruhi kualitas katering tersebut. Katering dapat berupa skala kecil dan skala besar. Salah satu contoh katering skala besar adalah katering penerbangan atau inflight catering.

Salah satu upaya untuk menghindari terjadinya keracunan dan penularan penyakit, katering dapat menerapkan higiene sanitasi makanan. Menurut Departemen Kesehatan Republik Indonesia pada Tahun 2004 menjelaskan bahwa higiene merupakan suatu upaya kesehatan dengan cara memelihara dan melindungi kebersihan individu, sebagai 
contoh tindakan higiene adalah mencuci tangan sebelum dan sesudah makan ${ }^{1}$. Sedangkan menurut Widyawati (2002), higiene adalah usaha untuk mencegah terjadinya penyakit yang menitik beratkan pada usaha perseorangan atau manusia beserta dengan lingkungan tempat orang tersebut berada².

Sanitasi memiliki arti yang mirip dengan higiene. Hanya saja bedanya jika higiene fokus pada aktivitas manusia, jika sanitasi fokus ke lingkungan manusia, sebagai contohnya yaitu tersedianya air bersih untuk cuci tangan sebelum dan sesudah makanan. Menurut WHO, sanitasi merupakan salah satu usaha untuk mengawasi faktor-faktor yang berasal dari lingkungan fisik yang akan berpengaruh kepada manusia, terutama halhal yang dapat memberikan efek merusak perkembangan fisik, kesehatan dan kelangsungan hidup ${ }^{3}$.

Higiene dan sanitasi memiliki hubungan yang sangat erat dan saling berhubungan satu sama lain. Apabila higiene seseorang baik akan tetapi sanitasinya tidak mendukung maka resiko terjadinya penyakit atau efek lainnya akan lebih tinggi, sebagai contoh yang diberikan oleh Departemen Kesehatan Republik Indonesia pada Tahun 2004 yaitu seseorang mencuci tangan sebelum dan sesudah makan, akan tetapi air yang tersedia tidak cukup sehingga cuci tangan yang dilakukan menjadi tidak sempurna. Higiene dan sanitasi memiliki tujuan untuk mencegah timbulnya penyakit dan keracunan serta gangguan kesehatan lainnya yang diakibatkan dari adanya interaksi faktor-faktor lingkungan hidup manusia ${ }^{1}$.

Menurut Prabu (2008), sanitasi makanan adalah suatu usaha pencegahan yang memfokuskan pada kegiatan atau tindakan yang perlu dilakukan untuk memastikan bahwa makanan dan minuman bebas dari bahaya yang beresiko mengganggu kesehatan, dimulai dari sebelum makanan dan minuman diproduksi sampai makanan dan minuman sudah siap dikonsumsi oleh konsumen ${ }^{4}$. Sedangkan menurut Departemen Kesehatan Republik Indonesia (2004), higiene sanitasi makanan dan minuman adalah suatu upaya yang dapat dilakukan untuk mengendalikan faktor tempat, orang, dan makanan yang memiliki kemungkinan untuk menimbulkan gangguan kesehatan dan keracunan makanan ${ }^{1}$. Makanan yang aman untuk dikonsumsi adalah makanan yang tidak tercemar dan tidak menyebabkan kerugian pada kesehatan manusia.

Berdasarkan Undang-Undang Republik Indonesia Nomor 18 Tahun 2012 Tentang Pangan, higiene sanitasi dilakukan agar pangan dapat dikonsumsi dengan aman. Dalam pengendalian risiko bahaya pada pangan, setiap orang yang terlibat dalam rantai pangan wajib mengendalikan risiko bahayanya, baik yang berasal dari bahan baku makanan, peralatan yang digunakan, sarana, proses produksi, maupun perseorangan sehingga keamanan terjamin ${ }^{5}$. Selain itu, perseorangan yang menyelenggarakan atau terlibat dalam proses produksi, penyimpanan, pengangkutan, dan/atau peredaran diwajibkan untuk memenuhi persyaratan sanitasi serta menjamin keamanan pangan untuk keselamatan manusia.

Dalam penerapannya, higiene sanitasi dapat diterapkan di dalam pengolahan makanan apapun termasuk dalam usaha katering, salah satunya adalah katering penerbangan atau inflight catering. Penerapan higiene sanitasi makanan pada inflight catering sangat penting. $\mathrm{Hal}$ ini dikarenakan kontaminasi yang disebabkan oleh mikrobiologi dapat membawa masalah yang serius yaitu wabah keracunan yang dapat terjadi saat pesawat sedang dalam penerbangan. Salah satu media penularan mikrobiologi adalah melalui makanan. Kasus keracunan dalam penerbangan pertama kali terinvestigasi pada tahun 1947. Sejak saat itu, dilaporkan setidaknya 45 kasus keracunan makanan yang berhubungan dengan penerbangan terjadi. Pada tahun 1972, salah satu maskapai penerbangan di Australia mengalami keracunan akibat makanan. Keracunan makanan yang diakibatkan oleh Kolera terjadi pada penumpang kelas ekonomi dalam penerbangan dari London ke Sydney. Kasus keracunan ini menyebabkan 1 orang meninggal dunia ${ }^{6}$. Pada tahun 2009, terjadi keracunan pada tiga kelompok penerbangan di Hawaii, Amerika Serikat yang diakibatkan 
oleh Shigella. Dalam kelompok pertama yaitu penerbangan menuju Jepang, terdapat 12 orang yang dikonfirmasi terinfeksi Shigella. Kelompok kedua adalah penerbangan dengan tujuan Ohio, Amerika Serikat, dan kelompok ketiga adalah penerbangan dengan tujuan Honolulu ${ }^{6}$.

Berdasarkan hasil penelitian yang dilakukan oleh Tabacchi dan Marshal (1998), sebanyak $30 \%$ penumpang pesawat terbang di Amerika berpendapat bahwa kualitas makanan yang dihidangkan dalam penerbangan memiliki peranan yang penting dalam memilih maskapai penerbangan ${ }^{6}$. Maka dari itu, kualitas makanan harus diperhatikan dalam usaha katering, termasuk inflight catering.

Sebagai salah satu penyedia inflight catering dan penyedia logistik penerbangan bertaraf internasional terutama logistik untuk Garuda Indonesia, PT. Aerofood Indonesia yang telah berdiri sejak tahun 1970 memiliki visi untuk menjadi penyedia jasa makanan dan layanan berkualitas premium di Asia Tenggara. Salah satu upaya untuk meningkatkan kualitas makanan yang disajikan adalah dengan menerapkan higiene sanitasi makanan.

Menurut Departemen Kesehatan Republik Indonesia (2004), agar makanan dan minuman yang merupakan kebutuhan seharihari dapat memberikan manfaat dan terhindar dari efek buruk yang dibawa, maka makanan dan minuman harus dikelola dengan baik dan benar ${ }^{1}$. Pengelolaan yang baik dan benar pada dasarnya adalah mengelola makanan dan minuman dengan berdasarkan kaidah-kaidah dari prinsip higiene sanitasi makanan.

Tujuan dari penulisan artikel ini adalah untuk mengetahui dan mempelajari apakah penerapan higiene dan sanitasi makanan khususnya pada main course Garuda Indonesia yang diproduksi oleh PT. Aerofood Indonesia sudah sesuai standar, dimulai dari pemilihan bahan baku makanan, penyimpanan bahan baku makanan, pengolahan makanan, penyimpanan makanan matang, pengangkutan makanan, dan penyajian makanan. Pemilihan main course Garuda Indonesia dalam artikel ini karena Garuda Indonesia merupakan maskapai penerbangan nasional yang membawa lebih dari 25 juta penumpang setiap tahunnya. Apabila makanan yang disajikan untuk penumpang tidak sesuai standar, maka akan dapat menyebabkan terjadinya wabah keracunan makanan.

\section{METODE}

Penelitian ini merupakan penelitian deskriptif atau gambaran. Metode penelitian ini menggunakan pendekatan kualitatif dengan menggunakan metode observasi dan wawancara. Sampel dalam penelitian ini adalah main course Garuda Indonesia yang diolah di PT. Aerofood Indonesia, Tangerang, Banten. Penelitian ini dilakukan dalam kurun waktu satu bulan dan dilaksanakan di PT. Aerofood Indonesia, Tangerang, Banten.

$$
\text { Penelitian ini menggunakan }
$$

instrument observasi yang disusun oleh PT. Aerofood Indonesia. Observasi dilakukan selama 11 hari dengan cara melihat langsung penerapan prinsip higiene sanitasi makanan di PT. Aerofood Indonesia. Pelaksanaan observasi dilakukan dengan pendampingan oleh petugas Quality Control di PT. Aerofood Indonesia. Selain observasi, wawancara juga dilakukan untuk mendapatkan informasi terkait penerapan prinsip higiene sanitasi makanan pada main course Garuda Indonesia di PT. Aerofood Indonesia.

\section{HASIL DAN PEMBAHASAN}

PT. Aerofood Indonesia merupakan perusahaan yang bergerak di bidang utama produksi makanan katering dan penyedia layanan pendukung penerbangan lainnya meliputi selimut, majalah, dan lain-lain. Produksi makanan di PT. Aerofood Indonesia dilakukan selama 24 jam penuh dengan tiga pembagian shift bagi para karyawannya, shift pertama bekerja dari pukul 00:00-08:00, shift kedua bekerja dari pukul 08:00-16:00, dan shift ketiga bekerja dari pukul 16:00-00:00.

Pelayanan yang diberikan oleh PT.Aerofood untuk maskapai penerbangan hanya sebatas penyedia makanan serta fasilitas penunjang lainnya. Untuk pelayanan yang akan diterima oleh penumpang masingmasing maskapai, diserahkan kepada kru 
maskapai yang sedang bertugas pada penerbangan tersebut. Dalam memproduksi makanan dengan kualitas baik setiap harinya untuk penerbangan domestik maupun internasional, perusahaan ini memperkerjakan kurang lebih 5.500 karyawan professional. Maskapai yang menggunakan pelayanan jasa dari PT. Aerofood Indonesia tidak hanya Garuda Indonesia, terdapat juga maskapai Japan Airlines, Korean Air, Singapore Airlines, Emirates, Royal Brunei, Malaysian Airlines, Cathay Pacific, Qantas Airways, China Airlines, Japan Asia Airways, EVA Air, Citilink, dan beberapa pesawat charter.

Dalam penyelenggaraan makanan agar menciptakan makanan yang berkualitas dan aman, penerapan higiene sanitasi makanan perlu dilakukan. Dalam penerapannya, makanan harus diperhatikan mutunya selama proses produksi. Selain makanan yang diperhatikan, penjamah makanan juga harus diperhatikan sanitasinya agar dapat meminimalisir terjadinya pencemaran baik biologi, kimia, maupun fisik yang dapat terjadi.

Dalam penerapan higiene sanitasi makanan, terdapat beberapa aspek yang harus diperhatikan. Terdapat enam aspek dalam penerapan higiene sanitasi makanan, dimulai dari pemilihan bahan baku makanan hingga penyajian makanan matang.

\section{Prinsip I: Pemilihan Bahan Baku Makanan Saat Penerimaan Bahan Makanan}

Menurut Kusmayadi (2008), kualitas bahan makanan yang baik dapat dilihat melalui ciri-ciri fisik dan mutunya ${ }^{7}$. Kualitas bahan makanan yang baik yaitu bahan makanan yang terbebas dari pencemaran termasuk pencemaran kimia seperti pestisida dan juga kerusakan. Dalam pemilihan bahan baku makanan yang dilakukan oleh PT. Aerofood sudah sesuai dengan Kusmayadi (2008), yaitu bahan baku makanan terbebas dari pencemaran dan kerusakan?

Dalam pemilihan bahan baku makanan, PT. Aerofood akan melakukan seleksi yang dilakukan oleh petugas Quality Control di bagian receiving atau bagian penerimaan. Pemilihan bahan baku dilakukan mulai dari memilih supplier bahan baku. Supplier bahan baku yang dipilih adalah supplier yang dapat dipercaya dan diverifikasi oleh pihak yang berwenang melalui pengecekan sumber pasokan dan pengakuan (bersertifikasi). Petugas yang bertugas akan memeriksa alat angkut yang digunakan untuk mengangkat bahan baku. Pemeriksaan yang dilakukan meliputi kebersihan alat angkut yang digunakan, pemisahan antara bahan baku makanan dan bukan makanan, pemeriksaan suhu, dan pemeriksaan tanda keberadaan hama.

Selanjutnya akan dilakukan pemilihan bahan baku makanan. Bahan baku makanan akan dicek secara acak dan dilihat melalui ciriciri fisiknya yang meliputi warna, bentuk, kesegaran, bau, dan lain-lain. Untuk buahbuahan dan sayuran seperti strawberry dan buncis akan disortir oleh petugas untuk menentukan mana yang akan diterima dan yang akan dikembalikan kepada supplier. Selain disortir, buah-buahan akan diukur tingkat kemanisannya dengan menggunakan Refraktometer. Apabila terdapat bahan baku makanan yang tidak sesuai dengan spesifikasi yang telah ditentukan, maka bahan makanan tersebut akan ditolak dengan surat berita yang diberikan kepada pihak supplier yang bersangkutan.

Syarat untuk produk makanan beku adalah suhu makanan harus $<-8^{\circ} \mathrm{C}$ serta tidak terdapat tanda pernah dithawing sebelumnya. Sedangkan untuk bahan baku dingin memiliki suhu maksimal $8^{\circ} \mathrm{C}$. Semua bahan baku yang akan diterima harus bebas dari kerusakan dan pencemaran.

Dalam pemilihan bahan baku makanan, mobil pengangkut yang digunakan oleh masing-masing supplier dalam pengangkutan bahan makanan juga akan diukur suhunya dan diperiksa untuk memastikan kualitas bahan makanan yang diterima. Hal tersebut dilakukan karena mobil pengangkut yang digunakan dalam proses pengiriman memiliki kaitan dengan kualitas bahan baku makanan mengingat adanya jarak dan waktu antara pihak supplier ke PT. Aerofood Indonesia. Apabila suhu mobil pengangkut tidak sesuai standar, maka dapat terjadi pertumbuhan mikroorganisme pada produk. Sebagai contoh yaitu pada produk beku (frozen), dimana salah 


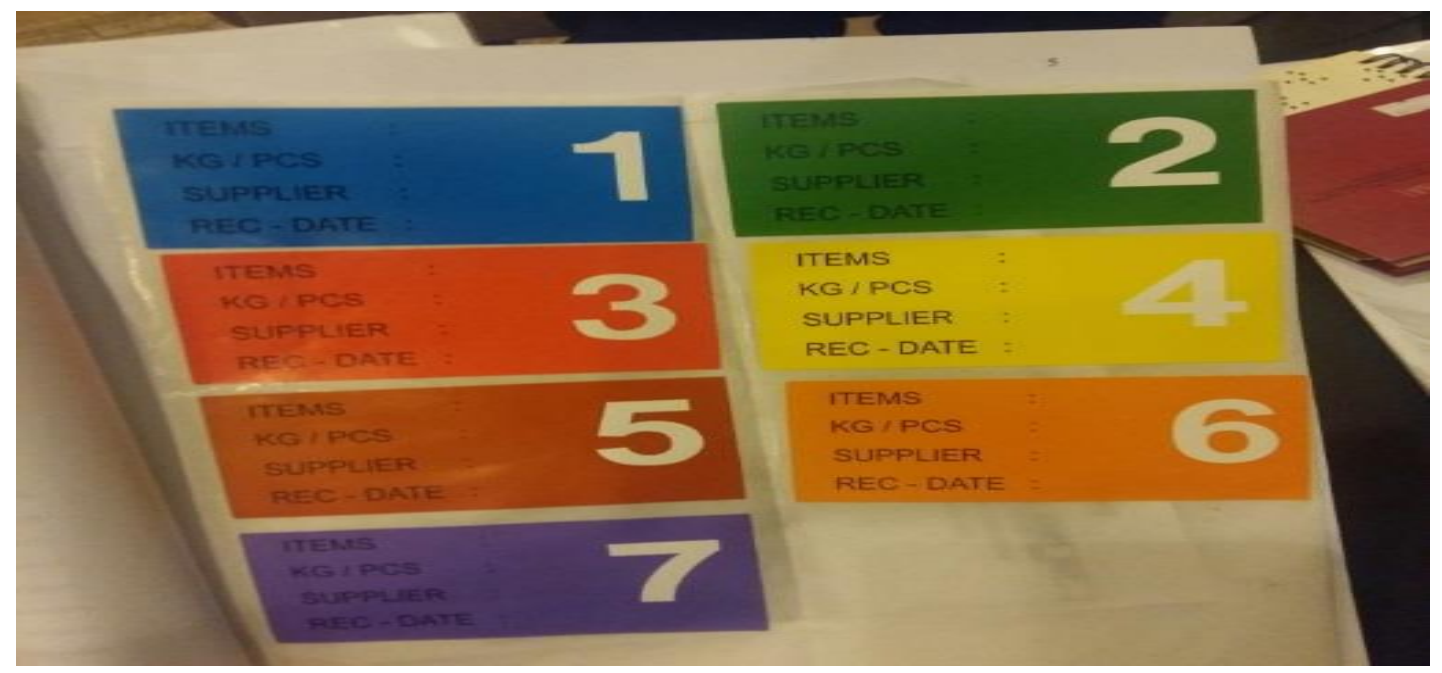

Gambar 1. Label Harian

satu syarat agar produk diterima adalah suhu produk tidak lebih dari $-8^{\circ} \mathrm{C}$. Untuk mempertahankan suhu pada produk, maka suhu pada mobil pengangkut juga harus disesuaikan.

Bahan baku makanan akan dipisahkan berdasarkan jenisnya, yaitu buah-buahan, sayur-sayuran, dry goods seperti minuman kemasan, dan lain-lain, frozen, chill, dan ready to eat food seperti roti, biskuit, dan lain-lain. Pemisahan bahan baku makanan dipisahkan menggunakan beberapa container yang berbeda-beda sesuai dengan jenis bahan baku makanannya dan container bahan makanan yang telah diterima diberi label terlebih dahulu untuk menandakan kapan bahan makanan tersebut diterima. Label yang digunakan memiliki warna serta nomor yang berbeda-beda setiap harinya.

\section{Prinsip II: Penyimpanan Bahan Makanan}

Menurut Kusmayadi (2008), proses penyimpanan makanan merupakan suatu proses agar suatu bahan makanan tidak mudah rusak dan kehilangan kandungan gizinya ${ }^{7}$. Sebelum dilakukan penyimpanan, bahan makanan harus dibersihkan terlebih dahulu. Cara membersihkan bahan makanan yang dapat dilakukan salah satunya adalah dengan mencuci bahan makanan, kemudian dikeringkan agar tidak terdapat air pada bahan makanan, dan kemudian dibungkus menggunakan pembungkus yang bersih dan disimpan di ruangan dengan suhu rendah.

Berdasarkan Departemen Kesehatan Republik Indonesia tahun 2004, bahan makanan yang telah diterima harus segera dilakukan penyimpanan yang sesuai untuk meminimalisir terjadinya pencemaran yang disebabkan oleh mikroorganisme karena kesalahan penyimpanan yang dapat dapat berakibat fatal pada penurunan mutu dan keamanan pangan ${ }^{3}$. Terdapat empat cara penyimpanan yang dapat dilakukan untuk meminimalisir kerusakan dan kehilangan zat gizi berdasarkan suhunya, yaitu: Penyimpanan sejuk (cooling), yaitu penyimpanan dengan suhu $10^{\circ} \mathrm{C}-15^{\circ} \mathrm{C}$ untuk jenis minuman, buah, es krim, dan sayuran. Penyimpanan dingin (chilling), yaitu penyimpanan dengan suhu $4^{\circ} \mathrm{C}-10^{\circ} \mathrm{C}$ untuk bahan makanan yang berprotein yang akan segera diolah kembali. Penyimpanan dingin sekali (freezing), yaitu suhu penyimpanan dengan suhu $0^{\circ} \mathrm{C}-4^{\circ} \mathrm{C}$ untuk bahan protein yang mudah rusak untuk jangka waktu sampai 24 jam. Penyimpanan beku (frozen), yaitu penyimpanan dengan suhu $<0^{\circ} \mathrm{C}$ untuk bahan makanan protein yang mudah rusak untuk jangka waktu >24 jam.

Tempat penyimpanan bahan makanan yang terdapat pada PT. Aerofood Indonesia dalam keadaan bersih serta kedap air dan tertutup. Selain itu bahan baku makanan akan disimpan sesuai dengan jenis makanannya, sehingga tidak bersatu antara satu jenis 
produk dengan produk lainnya. Sebelum setiap bahan makanan dimasukkan ke tempat penyimpanan yang tersedia, bahan makanan yang telah diterima diberi label terlebih dahulu untuk menandakan kapan bahan makanan tersebut diterima. Label yang digunakan memiliki warna serta nomor yang berbeda-beda setiap harinya.

Dalam penyimpanan bahan baku makanan, PT. Aerofood Indonesia memberikan jarak antara makanan dengan lantai dan memberikan jarak dengan langitlangit, sehingga makanan tidak langsung bersentuhan dengan lantai dan langit-langit. Hal ini sesuai dengan syarat penyimpanan menurut Depkes RI (2011) yaitu jarak makanan dengan lantai adalah $15 \mathrm{~cm}$, jarak makanan dengan dinding adalah $5 \mathrm{~cm}$, dan jarak makanan dengan langit-langit adalah 60 $\mathrm{cm}^{8}$.

Selanjutnya bahan makanan akan dipisahkan antara cold store dan dry store. Terdapat 7 chiller di dalam cold store. Chiller ini akan menjadi tempat untuk penyimpanan bahan makanan yang belum diolah. Masingmasing chiller memiliki suhu yang berbedabeda tergantung makanan yang disimpan. Berikut tabel penyimpanan bahan makanan yang dilakukan oleh PT. Aerofood Indonesia:

Tabel 1. Penyimpanan Bahan Baku Makanan

Bahan Baku Suhu Ruang Penyimpanan

\begin{tabular}{cc} 
& (Chiller) \\
\hline Buah-buahan & $3^{\circ} \mathrm{C}-9^{\circ} \mathrm{C}$ \\
Sayur-sayuran & $3^{\circ} \mathrm{C}-9^{\circ} \mathrm{C}$ \\
Bumbu jadi & $3^{\circ} \mathrm{C}-9^{\circ} \mathrm{C}$ \\
Telur & $3^{\circ} \mathrm{C}-9^{\circ} \mathrm{C}$ \\
Keju & $0^{\circ} \mathrm{C}-5^{\circ} \mathrm{C}$ \\
$\begin{array}{c}\text { Bahan baku siap } \\
\text { pakai (Yoghurt, } \\
\text { sirup, dan lain- } \\
\text { lain). }\end{array}$ & $0^{\circ} \mathrm{C}-5^{\circ} \mathrm{C}$ \\
Produk beku & $-18^{\circ} \mathrm{C}$ sampai $-30^{\circ} \mathrm{C}$ \\
\hline
\end{tabular}

Penyimpanan bahan makanan yang dilaksanakan oleh PT. Aerofood Indonesia sudah sesuai dengan Departemen Kesehatan Republik Indonesia (2004), yaitu penyimpanan bahan makanan dibedakan antar bahan makanan dan disesuaikan suhunya ${ }^{1}$.

\section{Prinsip III: Pengolahan Makanan}

Menurut Departemen Kesehatan Republik Indonesia (2004), pengolahan makanan merupakan suatu proses perubahan bentuk dari bahan mentah menjadi makanan yang siap dikonsumsi ${ }^{1}$. Untuk menciptakan makanan yang baik, maka proses pengolahan harus mengikuti prinsip-prinsip higiene sanitasi makanan. Dalam pengolahan makanan terdapat hal yang harus diperhatikan kebersihannya, yaitu penjamah makanan, cara pengolahan makanan, dan tempat pengolahan makanan.

Penjamah makanan merupakan seorang pekerja yang betugas untuk menjamah makanan dimulai dari persiapan bahan baku hingga penyajian makanan. Kualitas makanan yang disajikan dipengaruhi oleh pengetahuan, sikap, dan tindakan dari penjamah makanan. Untuk mencegah terjadinya pencemaran, terdapat syarat untuk penjamah makanan menurut Departemen Kesehatan Republik Indonesia (2004), yaitu menutup luka terbuka, menggunakan hairnet atau penutup kepala, sedang tidak menderita penyakit menular seperti flu, batuk, influenza, diare, dan lainlain, menjaga kebersihan tangan, rambut, kuku, dan pakaian, mencuci tangan setiap kali akan menangani makanan, menggunakan alat saat menjamah makanan agar tidak bersentuhan langsung dengan kulit, tidak merokok atau menggaruk anggota badan, dan tidak batuk maupun bersin di depan makanan tanpa menutupnya ${ }^{1}$.

Penjamah makanan di PT Aerofood Indonesia diwajibkan untuk menggunakan hairnet, masker, serta sarung tangan selama proses produksi. Hal ini dilakukan agar dapat mengurangi resiko timbulnya pencemaran baik fisik, biologi maupun kimia yang kemungkinan terbawa oleh penjamah makanan. Hal ini sesuai dengan syarat penjamah makanan menurut Departemen Kesehatan Republik Indonesia ${ }^{1}$.

Cara pengolahan makanan di PT. Aerofood Indonesia yaitu makanan dimasak dalam porsi besar. Pada saat proses pengolahan, terdapat suhu inti produk yang akan diperiksa. Setiap suhu inti akan berbedabeda setiap bahan pangan, pengukuran pada produk akan dilakukan setiap akhir 
pemasakan dengan mengukur suhu inti produk. Seperti telur harus memiliki suhu inti sebesar $74^{\circ} \mathrm{C}$, produk yang mengandung daging (sapi, kambing, unggas), ikan dan pasta harus memiliki suhu inti $74^{\circ} \mathrm{C}$, produk yang mengandung udang dan kerang (seafood) harus memiliki suhu inti sebesar $65^{\circ} \mathrm{C}$, produk yang di "grilled" seperti sate harus memiliki suhu sebesar $65^{\circ} \mathrm{C}$, dan produk yang mengandung susu atau santan harus memiliki suhu inti sebesar $72^{\circ} \mathrm{C}$. Apabila produk yang telah dimasak belum mencapai suhu yang telah ditentukan, maka produk tersebut harus dimasak kembali hingga mencapai suhu yang telah ditentukan.

Makanan yang sudah diolah selanjutnya akan dimasukkan ke blast chiller untuk menurunkan suhunya yang semula $60^{\circ} \mathrm{C}$ menjadi $15^{\circ} \mathrm{C}$ dalam waktu maksimal 4 jam. Apabila suhu makanan belum turun dalam waktu 4 jam, maka makanan tersebut harus dibuang.

Karena pemasakan bahan makanan dilakukan dalam jumlah besar, maka makanan tersebut harus dibuat menjadi per porsi. Hal tersebut akan dilakukan di Hot Dishing. Sebelum dilakukan dishing, produk makanan yang akan dibuat per porsi akan disortir terlebih dahulu untuk mengurangi adanya resiko pencemaran baik fisik, maupun biologi. Pada saat dishing makanan, harus dilakukan dalam waktu tidak lebih dari 45 menit dengan suhu ruangan maksimal $21^{\circ} \mathrm{C}$ dan suhu permukaan produk maksimal adalah $15^{\circ} \mathrm{C}$. Apabila hal tersebut tidak dapat tercapai maka produk tersebut harus dibuang. Setelah didishing, produk akan dimasukkan kembali ke chiller dan saat akan adanya penerbangan, makanan sesuai menu harian akan dibawa ke MTSU atau Meal Tray Set Up atau penataan masing-masing tray dan akan dimasukkan ke masing-masing troli maskapai penerbangan.

Tempat pengolahan makanan yaitu pada proses pemasakan adalah Hot Kitchen. Hot Kitchen yang dimiliki oleh PT Aerofood Indonesia merupakan dapur yang kedap air, bersih, tidak licin, memiliki saluran air, serta terdapat ventilasi yang cukup, dan cahaya yang cukup.

Hot Dishing merupakan lokasi untuk pemorsian atau dishing menu. Hot Dishing memiliki bangunan atau ruangan yang tidak licin, kedap air, memiliki suhu yang tidak panas, dan cukup pencahayaan. Lokasi Hot Kitchen dan Hot Dishing saling berdekatan.

\section{Prinsip IV: Penyimpanan Makanan Matang}

Menurut Depkes RI, 2004 makanan yang telah matang harus menggunakan wadah yang bersih dan aman bagi kesehatan dan tutup makanan dan minuman harus dalam keadaan bersih dan tidak mencemari makanan. Selain itu makanan matang harus disimpan secara terpisah sesuai dengan jenisnya ${ }^{1}$. Di PT. Aerofood Indonesia, makanan yang telah matang dan sudah di dishing selanjutnya akan diproses di dalam chiller. Setelah dari blast chiller, makanan yang telah jadi akan disimpan di chiller. Sebelum didishing, meal akan disortir terlebih dahulu untuk memastikan tidak terdapat foreign object atau objek asing pada makanan. Makanan yang sudah di dishing paling lama disimpan dalam chiller adalah selama 3 hari. Apabila sudah melebihi waktu yang telah ditentukan, maka makanan tersebut akan dibuang. Untuk mengetahui kapan makanan tersebut dimasukkan ke chiller, pada tray makanan tersebut akan diberi label sesuai dengan harinya.

Makanan matang yang disimpan di chiller akan dipisahkan pada masing-masing tray dan menggunakan penutup plastik sehingga tidak akan tercampur antar produk. Selain itu penyimpanan makanan matang juga diberi jarak antara langit-langit dan juga lantai.

\section{Prinsip V: Pengangkutan Makanan}

Pengangkutan makanan berperan dalam pencegahan terjadinya pencemaran makanan. Dalam proses pengangkutan makanan banyak pihak yang terkait mulai dari persiapan sampai kendaraan yang digunakan dalam pengangkutan makanan itu sendiri.

Bahan makanan yang akan digunakan akan diangkut menggunakan tray ataupun troli, tergantung dengan jumlah yang dibutuhkan dan jarak yang ditempuh. Apabila hanya mengambil dari chiller yang lokasinya dekat dengan jumlah yang tidak terlalu banyak, biasanya akan menggunakan tray. Namun apabila komponen yang dibutuhkan 
tergolong banyak, maka bahan akan diambil menggunakan troli.

Makanan siap santap yang telah selesai diolah dan di dishing, akan dibawa ke MTSU (Meal Tray Set Up) untuk ditata kembali di troli untuk pesawat. Makanan yang telah ditata di MTSU akan disimpan terlebih dahulu di dalam chiller selama kurang lebih 3-4 jam sampai menjelang penerbangan sebelum akhirnya dibawa ke loading dock untuk dimasukkan ke dalam high lift truck dan diantarkan ke pesawat sebelum disajikan ke penumpang pesawat.

\section{Prinsip VI: Penyajian Makanan}

Penyajian makanan yang menarik akan memberikan nilai tambah dalam menarik pelanggan. Teknis penyajian makanan untuk konsumen memiliki berbagai cara selama tetap mengikuti prinsip hygiene sanitasi makanan yang baik dan benar. Waktu kedatangan makanan ke pesawat adalah tiga puluh menit sebelum keberangkatan. Makanan yang akan dikirimkan ke pesawat akan didistribusikan menggunakan high lift truck. Alat yang selanjutnya digunakan dalam distribusi makanan kepada konsumen adalah troli yang dilengkapi dengan roda penggerak.

Sebelum makanan diangkut oleh high lift truck, suhu makanan akan diperiksa kembali. Suhu makanan saat keluar dari final holding tidak lebih dari $8^{\circ} \mathrm{C}$. Jika sebelum penyajian makanan ditemukan produk yang rusak, maka produk tersebut akan dibuang dan dicatat dalam laporan. Makanan yang disajikan harus pada tempat yang bersih, peralatan yang digunakan bersih, sirkulasi udara dapat berlangsung, penyaji atau penjamah berpakaian bersih dan rapih menggunakan celemek dan penutup kepala serta tidak diperbolehkan adanya kontak langsung dengan makanan yang disajikan. Dalam penyajian makanan kepada penumpang selanjutnya akan diserahkan kepada kru masing-masing maskapai yang sedang bertugas pada penerbangan tersebut.

Tempat atau wadah yang digunakan oleh PT. Aerofood Indonesia untuk menyajikan main course Garuda Indonesia adalah menggunakan melamin untuk kelas bisnis dan aluminium meal dish untuk kelas ekonomi. Untuk penutupnya menggunakan kertas aluminium foil.

\section{KESIMPULAN}

Dalam penerapan prinsip higiene sanitasi makanan, PT. Aerofood Indonesia telah melaksanakannya, dimulai dari proses penerimaan bahan baku makanan hingga penyajian makanan. Dengan menerapkan prinsip higiene sanitasi makanan, diharapkan mampu meminimalisir adanya hal merugikan yang disebabkan oleh makanan.

\section{ACKNOWLEDGMENT}

Peneliti mengucapkan terimakasih kepada PT Aerofood Indonesia, Tangerang, Banten yang telah mengizinkan sehingga penelitian ini dapat terlaksana.

\section{REFERENSI}

1. Depkes. Higiene Sanitasi Makanan dan Minuman. Dirjen PPM dan PLP. Depkes RI Jakarta. 2004.

2. Widyawati, Retno, Yuliarsih. Hygiene dan Sanitasi. Indonesia: Grasindo; 2002.

3. WHO. Sanitation and Hygiene Promotion. 2005. Diakses dari http://www.who.int/water_sanitation_ health/hygiene/sanhygpromo.pdf.

4. Prabu. Higiene dan Sanitasi Makanan. 2008. Diakses dari http//gmpg.org.

5. Undang-Undang Republik Indonesia Nomor 18 Tahun 2012 Tentang Pangan. 2012.

6. King, T. Inflight Catering. Journal of Tourism and Hospitality Research 2001;32:181-184.

7. Kusmayadi. Cara Memilih dan Mengolah Makanan Untuk Perbaikan Gizi Masyarakat. 2008. Diakses dari: http://database.deptan.go.id.

8. Peraturan Menteri Kesehatan Republik Indonesia Nomor 1096/MENKES/PER/VI/2011 Tentang Higiene Sanitasi Jasaboga. 2011 